Finanse, Rynki Finansowe, Ubezpieczenia nr 3/2017 (87), cz. 1

\title{
Funkcja doradcza na tle aktualnych i perspektywicznych celów audytu wewnętrznego
}

\author{
Kazimiera Winiarska"
}

\begin{abstract}
Streszczenie: $\mathrm{Cel}$ - Celem artykułu jest ocena realizacji funkcji doradczej w zadaniach audytu wewnętrznego.

Metodologia badania - Wykorzystano wyniki badań ankietowych instytutów audytu wewnętrznego i firmy audytorskiej.

Wynik - Według przeprowadzonych badań naukowych w zadaniach audytowych ankietowani wymieniają czynności doradcze dla kierownictwa jednostek.

Oryginalność/wartość - Dzięki publikacjom zagranicznym uzyskano informacje o rankingu czynności audytowych. Zagraniczni audytorzy korzystają z kontaktów w ramach instytutów audytu wewnętrznego oraz większych możliwości finansowych przy badaniach ankietowych.
\end{abstract}

Słowa kluczowe: audyt wewnętrzny, funkcje audytu wewnętrznego, funkcja doradcza audytu wewnętrznego

\section{Wprowadzenie}

Audyt wewnętrzny ma na świecie wielowiekowe tradycje. Rozwój audytu wewnętrznego był uzależniony od sytuacji gospodarczej, politycznej i technologicznej. Początkowo w audycie wewnętrznym koncentrowano uwagę na aspektach finansowych, następnie rozszerzono zainteresowania również na aspekty niefinansowe. Aktualnie oczekuje się od audytorów wewnętrznych pełnienia funkcji doradczych. Rozmiary jednostek biznesowych i publicznych, źródła finansowania działalności i powiązania międzynarodowe powodują, że kierownictwo tych jednostek oczekuje wsparcia ze strony niezależnego audytu wewnętrznego.

\section{Aktualne i perspektywiczne cele audytu wewnętrznego}

Audyt wewnętrzny w Polsce nie ma długiej historii (od 2002 r.) i jest kojarzony wyłącznie z sektorem finansów publicznych. W krajach Europy Zachodniej ma dłuższą historię i występuje we wszystkich sektorach gospodarki narodowej.

" prof. zw. dr hab. Kazimiera Winiarska, Uniwersytet Szczeciński, WNEiZ, Instytut Rachunkowości, e-mail: kr234@wneiz.pl. 
Dla sprawdzenia jak w praktyce realizowane są zadania audytu wewnętrznego opracowano ankietę badawczą (Eulerich, 2014), którą opublikowano w Niemczech, Szwajcarii i Austrii. W ankiecie wzięło udział 2450 audytorów wewnętrznych. Najwięcej audytorów pochodziło z instytucji kredytowych i usług finansowych (27\%). Z sektora przemysłu było $22 \%$ audytorów. Pozostali ankietowani wywodzili się z innych branż.

Identyfikacja i ocena ryzyka są obecnie głównym celem zainteresowania kierownictwa organizacji. Są one istotne zarówno w okresie wyznaczania celów dla jednostki, jak i w przypadku niezrealizowania celów. Cele wyznaczone przez właścicieli zostają przekazane zarządom, a następnie oddziałom przedsiębiorstwa i poszczególnym pracownikom (Winiarska, 2017, s. 47).

Przykładami celów podstawowych, zdefiniowanych na potrzeby zapewnienia długoterminowego istnienia jednostki, są (rys. 1):

- zwiększenie zysku/obniżenie kosztów,

- maksymalizacja zysków kapitałowych/wzrost kursu akcji,

- minimalizacja ryzyka/identyfikacja oraz monitoring ryzyka,

- utrzymanie pozycji na rynku/zwiększenie liczby klientów,

- polepszenie wizerunku jednostki/spełnienie oczekiwań interesariuszy.

W obszarach istotnych dla realizacji celu wymienia się działania doradcze.

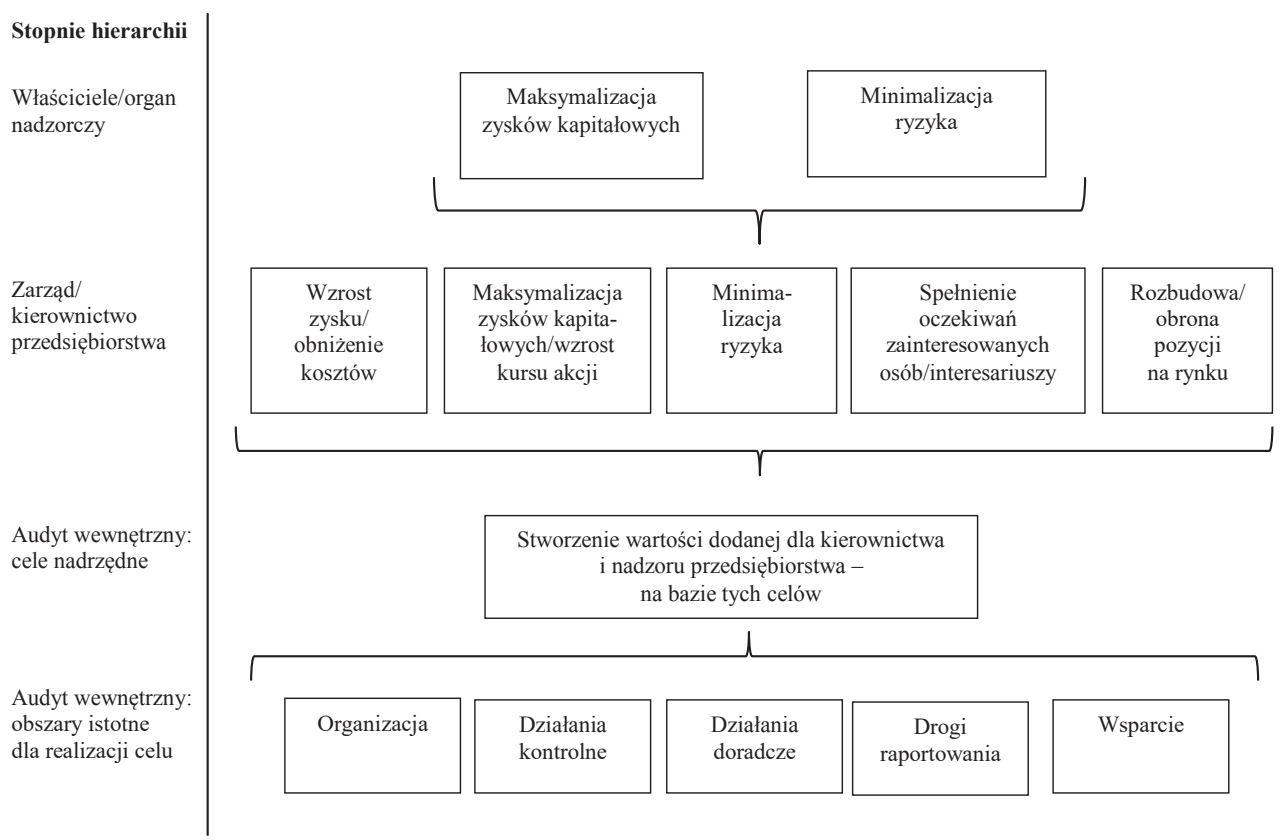

Rysunek 1. Hierarchia celów przedsiębiorstwa z punktu widzenia audytu wewnętrznego

Źródło: Eulerich (2014). 
Cele wyznaczone przez właścicieli i przekazane według hierarchii decyzji w jednostce wpływają również na funkcje audytu wewnętrznego. Audyt wewnętrzny powinien zabezpieczać wszystkie rodzaje aktywności jednostki i generowanie wartości dodanej (rys. 2).

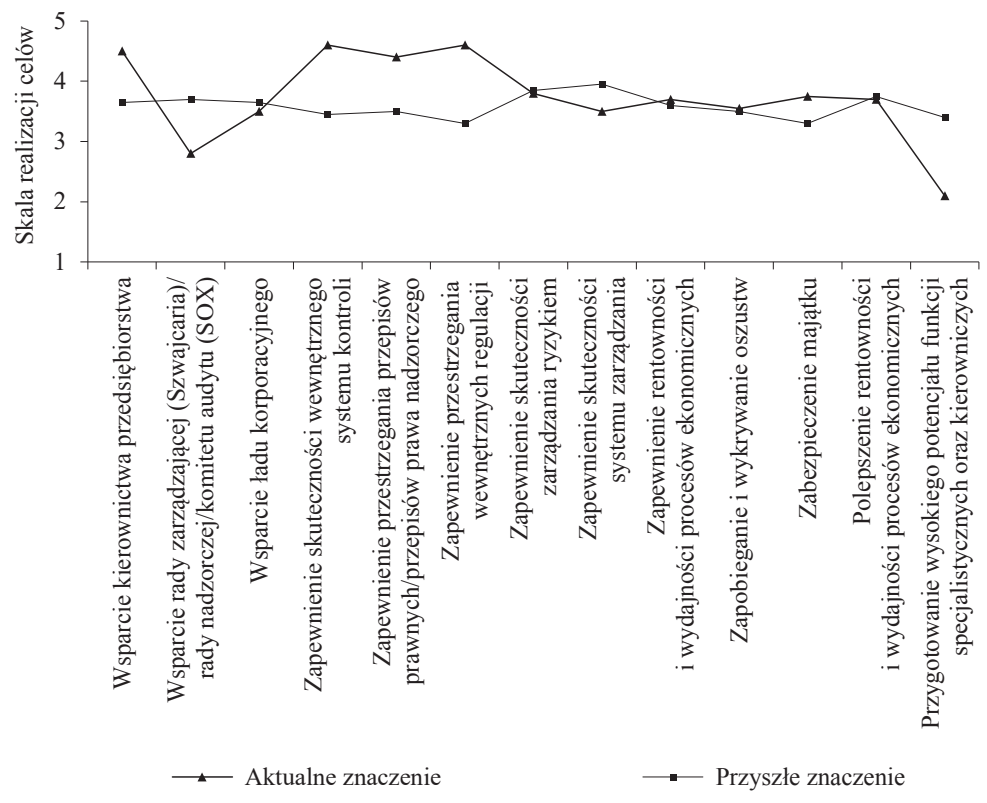

Rysunek 2. Cele i zadania audytu wewnętrznego

Źródło: Eulerich (2014).

Właściciele jasno wyznaczają cele jednostki, a zarząd dedukcyjnie przeprowadza transformację tych celów na własny użytek. Audytorzy wewnętrzni, pełniąc funkcję kontrolno-doradczą, powinni wpierać kierownictwo jednostki w transformacji celów.

Z analizy celów wyznaczonych przez właścicieli i ich związku przyczynowo-skutkowego, można wysnuć następujące wnioski:

- audyt wewnętrzny poprawia strukturę zarządzania,

- zarząd ma większą orientację w zakresie ryzyka,

- rada nadzorcza i właściciele są zadowoleni z osiąganej wydajności jednostki.

Różnorodne obszary zabezpieczania celów determinują wielowarstwowe zakresy zadań audytu wewnętrznego. Należy je połączyć z bezpośrednimi wytycznymi dla kierownictwa i pośrednimi wytycznymi dla nadzoru przedsiębiorstwa.

Aktualnie audyt wewnętrzny zdecydowanie wskazuje na różnice w ustalaniu priorytetów celów. W przyszłości ta różnorodność celów będzie mniejsza. W skali 1-5 (gdzie 5 oznacza - mocno wzrośnie, a 1 - może spadnie) audytorzy wskazali przyszłe cele i zadania. Większe znaczenie będą miały funkcje ,wsparcie kierownictwa przedsiębiorstwa”, 
„,zapewnienie skuteczności wewnętrznego systemu kontroli”, „zapewnienie przestrzegania przepisów prawnych”, ,zapewnienie przestrzegania wewnętrznych regulacji”. Wzrost znaczenia tych funkcji oznacza, że funkcjonowanie audytu wewnętrznego w przedsiębiorstwie poprawia się i pozyskuje nowe zasoby do realizacji swoich zadań doradczych.

W ankiecie poproszono również o ocenę intensywności współpracy audytu wewnętrznego z wewnętrznymi i zewnętrznymi instytucjami (rys. 3).

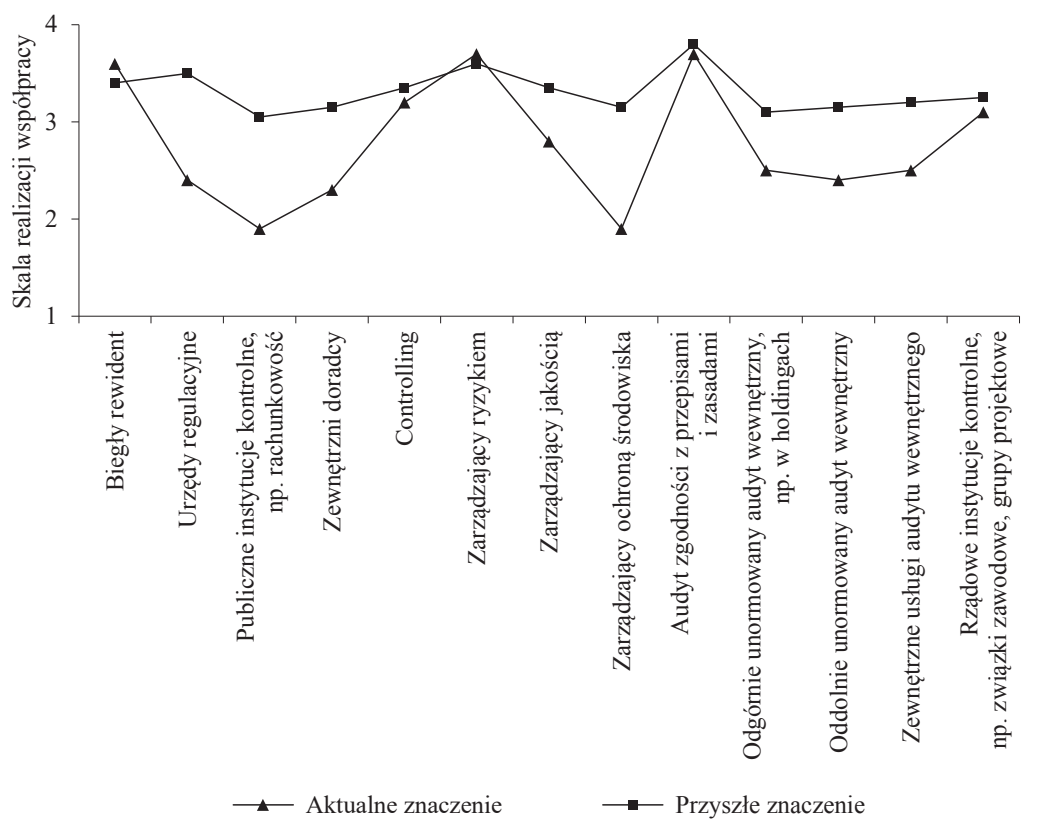

Rysunek 3. Intensywność współpracy audytu wewnętrznego z wewnętrznymi i zewnętrznymi instytucjami

Źródło: Eulerich (2014).

Szczególnie ważna jest współpraca z biegłym rewidentem, zarządzającymi ryzykiem i oceniającymi zgodność z przepisami i zasadami.

Dla oceny poglądów audytorów o przyszłości audytu wewnętrznego, poproszono o wskazanie ważniejszych tematów (obszarów) audytu wewnętrznego obecnie i za pięć lat (rys. 4).

Dynamiczne otoczenie organizacji powoduje wzrost trudności, które audyt wewnętrzny musi pokonać. Dużą rolę odgrywa doświadczenie, ale i zrozumienie specyfiki organizacji. Na rysunku 4 wskazano ważne obszary audytu wewnętrznego (w tym jego rolę doradczą w strategicznych decyzjach i audyt kontynuacji działalności). 


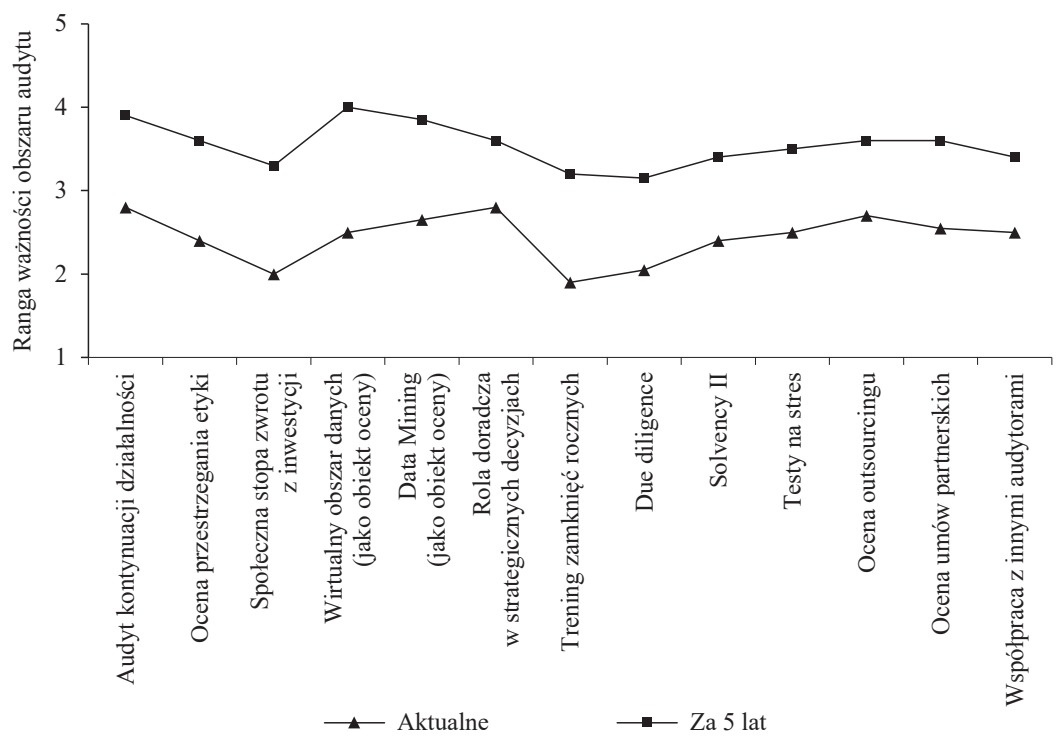

Rysunek 4. Perspektywiczne znaczenie ważniejszych tematów (obszarów) audytu wewnętrznego Źródło: Eulerich (2014).

\section{Główne obszary zainteresowania audytu wewnętrznego}

IIA przeprowadził w latach 2006 i 2010 wielostronne badania oceniające istotne obszary i wyniki audytu wewnętrznego. W badaniach oceniono również najważniejsze i najmniej ważne obszary działalności audytu wewnętrznego. W 2006 roku respondenci wskazali na następujące najważniejsze i najmniej ważne obszary działalności audytu wewnętrznego (tab. 1).

\section{Tabela 1}

Najbardziej i najmniej rozwinięte obszary działalności audytu wewnętrznego w 2006 roku

\begin{tabular}{lll}
\hline Lp. & Główne obszary zainteresowania & Obszary najmniejszego zainteresowania \\
\hline 1. & Zapobieganie oszustwom & Wynagrodzenia dla kadry kierowniczej wyższego szczebla \\
2. & Zarządzanie ryzykiem & Globalizacja \\
3. & Zgodność z regulacjami & Ochrona środowiska \\
4. & Nadzór korporacyjny & Nowo powstające rynki \\
\hline
\end{tabular}

Źródło: opracowanie własne na podstawie Burnaby, Hass (2009), s. 828.

Najważniejsze i najmniej ważne obszary działalności audytu wewnętrznego wskazane przez respondentów w 2010 roku zaprezentowano w tabeli 2. 


\section{Tabela 2}

Najbardziej i najmniej rozwinięte obszary działalności audytu wewnętrznego w 2010 roku

\begin{tabular}{|c|c|c|}
\hline Lp. & Główne obszary zainteresowania & Obszary najmniejszego zainteresowania \\
\hline 1. & Audyt operacyjny & $\begin{array}{l}\text { Wdrożenie rozszerzonego języka sprawozdawczości } \\
\text { biznesowej (XBRL) }\end{array}$ \\
\hline 2. & $\begin{array}{l}\text { Audyt zgodności z regulacjami kodeksu } \\
\text { (włącznie z ochroną prywatności) }\end{array}$ & Oceny wynagrodzeń kierownictwa wyższego szczebla \\
\hline 3. & Audyt ryzyka finansowego & $\begin{array}{l}\text { Wdrażanie Międzynarodowych Standardów } \\
\text { Sprawozdawczości Finansowej (IFRS) }\end{array}$ \\
\hline 4. & $\begin{array}{l}\text { Dochodzenia w sprawie oszustw } \\
\text { i nieprawidłowości }\end{array}$ & $\begin{array}{l}\text { Działania społeczne i związane z ochroną środowiska } \\
\text { (korporacyjna odpowiedzialność społeczna, środowisko) }\end{array}$ \\
\hline 5. & Ochrona sprawności struktur kontrolnych & Audyty jakościowe/ISO \\
\hline
\end{tabular}

Źródło: opracowanie własne na podstawie: Allegrini, D’Onza, Melville, Sarens, Selim (2011), s. 22.

Badania z 2010 roku wskazują, że obszar nadzoru i zarządzania ryzykiem jest coraz ważniejszy, a audyty finansowe i operacyjne pozostają na podobnym poziomie ważności.

Z raportu IIA wynika ranking czynności audytowych (tab. 3). Do zakresu czynności audytowych zaliczono 25 zadań i są one bardzo różnorodne, co świadczy o odpowiedzialności audytorów wewnętrznych w pełnieniu funkcji doradczych.

\section{Tabela 3}

Ranking czynności audytowych

\begin{tabular}{llc}
\hline Ranking czynności audytowych & Obecnie \\
\cline { 2 - 3 } & $\%$ & pozycja \\
\hline 1 & 2 & 3 \\
\hline Audyt operacyjny & 88,9 & 1 \\
Audyt zgodności z wymaganiami aktów wykonawczych & 75,1 & 2 \\
Audyt ryzyka finansowego & 71,6 & 3 \\
Badanie oszustw i nieprawidłowości & 71,2 & 4 \\
Ocena efektywności i systemów kontroli & 68,8 & 5 \\
Audyt ryzyka systemów informatycznych & 61,7 & 6 \\
Audyt ryzyka informacji & 61,4 & 7 \\
Audyt ryzyka procesów zarządzania & 56,6 & 8 \\
Audyt zarządzania projektami & 55,4 & 9 \\
Ocena zabezpieczeń i dochodzenia & 52,8 \\
Wsparcie audytu zewnętrznego & 52,0 \\
Audyt zarządzania & 49,9 \\
Przegląd ładu korporacyjnego & 10 \\
Testowanie i wsparcie odbudowy po katastrofie & 44,5 \\
Zapewnienie szkoleń w zakresie ryzyka/kontroli/zgodności dla pracowników & 13 \\
Audyt w outsourcingu & 40,5 \\
Audyt etyczny & 40,0 \\
Ocena zdolności do kontynuacji działalności & 35,0 & 14 \\
Przegląd powiązań między strategią i dokonaniami (balanced scorecard) & 32,1 & 16
\end{tabular}




\begin{tabular}{lll}
\hline 1 & 2 & 3 \\
\hline Przegląd należytej staranności dokonanych fuzji, przejęć itp. & 24,8 & 20 \\
Audyt jakości & 24,0 & 21 \\
Audyt społeczny i środowiska naturalnego & 19,6 & 22 \\
Przejście na MSR/MSSF & 19,4 & 23 \\
Audyt nagród & 18,5 & 24 \\
Wdrożenie XBRL & 5,3 & 25 \\
\hline
\end{tabular}

Źródło: opracowanie własne na podstawie Alkafaji, Hussain, Khallaf, Meldalawieh (2010), s. 24.

Na wzór badań opublikowanych przez instytuty audytu wewnętrznego, firma audytorska Grand Thornton przeprowadziła badania funkcji audytu wewnętrznego w polskich spółkach (Thornton, 2013). Badania zrealizowano w okresie marzec-maj 2013 roku. Ankietę skierowano do osób odpowiedzialnych za funkcję audytu wewnętrznego. Uzyskano odpowiedzi od 30 spółek. Były to spółki z udziałem Skarbu Państwa oraz spółki notowane na GPW, głównie finansowe i energetyczne.

Audyt wewnętrzny formalnie podlega możliwie najwyższemu szczeblowi kierownictwa (prezesowi lub członkom zarządu). 13\% audytorów wewnętrznych podlega bezpośrednio dyrektorowi finansowemu lub dyrektorowi innego działu. Niemal połowa komórek audytu wewnętrznego podlega radzie nadzorczej lub komitetowi audytu.

Wszystkie badane spółki zadeklarowały opracowywanie planu audytu. 71\% spółek ma sformalizowane zasady funkcjonowania audytu wewnętrznego. Przesłanki do wdrożenia audytu wewnętrznego wynikają najczęściej bezpośrednio z jego definicji. Należą do nich: dostarczanie systematycznej oceny funkcjonowania kontroli wewnętrznej, zarządzania ryzykiem oraz profesjonalnego doradztwa. W ostatnich latach zauważa się przesłanki zewnętrzne, np. wymogi właściciela (grupy kapitałowej) lub Dobre Praktyki Spółek Giełdowych.

Rodzaje realizowanych audytów wewnętrznych w latach 2009, 2011 i 2012 zaprezentowano na rysunku 5. Również w polskich spółkach zauważono funkcję doradczą audytu wewnętrznego. Obserwuje się spadek udziału audytów finansowych i wzrost udziału audytów operacyjnych. Audyt IT utrzymuje się w granicznych 40-46\%, a audyt prawny w granicach 21-24\%. Audyty ISO i etyczne stanowią margines działalności. Zapytani o kierunki audytu wewnętrznego w perspektywie 5 lat zarządzający spółkami zadeklarowali audyty operacyjne, doradztwo, IT i audyt finansowy. Wygląda na to, że trend spadkowy audytów finansowych zostanie zatrzymany. Być może ma to związek z obserwowaną w ostatnich latach dużą liczbą nadużyć finansowych.

Zgodnie ze standardami, rozwiązaniem zapewniającym optymalny poziom niezależności organizacyjnej audytu wewnętrznego jest sytuacja, gdy podlega on radzie nadzorczej lub komitetowi audytu, a administracyjnie prezesowi zarządu (dyrektorowi generalnemu). Podległość administracyjną audytu wewnętrznego przedstawiono na rysunku 6.

Obserwuje się wzrost podległości audytorów wewnętrznych dyrektorowi finansowemu lub dyrektorowi innego działu (z 1\% do 13\%). W większości przypadków podległość dotyczy dyrektora finansowego, co może skutkować nastawieniem audytorów wewnętrznych 
na kwestie finansowe. Dodatkowo umiejscowienie audytu wewnętrznego na niższym poziomie (dyrektorów innych działów) powoduje, że nie ma on zagwarantowanego odpowiedniego wsparcia ze strony zarządu. Audytorzy wewnętrzni, obok podstawowej działalności, wykonują wiele dodatkowych zadań, głównie z zakresu controlligu i rachunkowości.

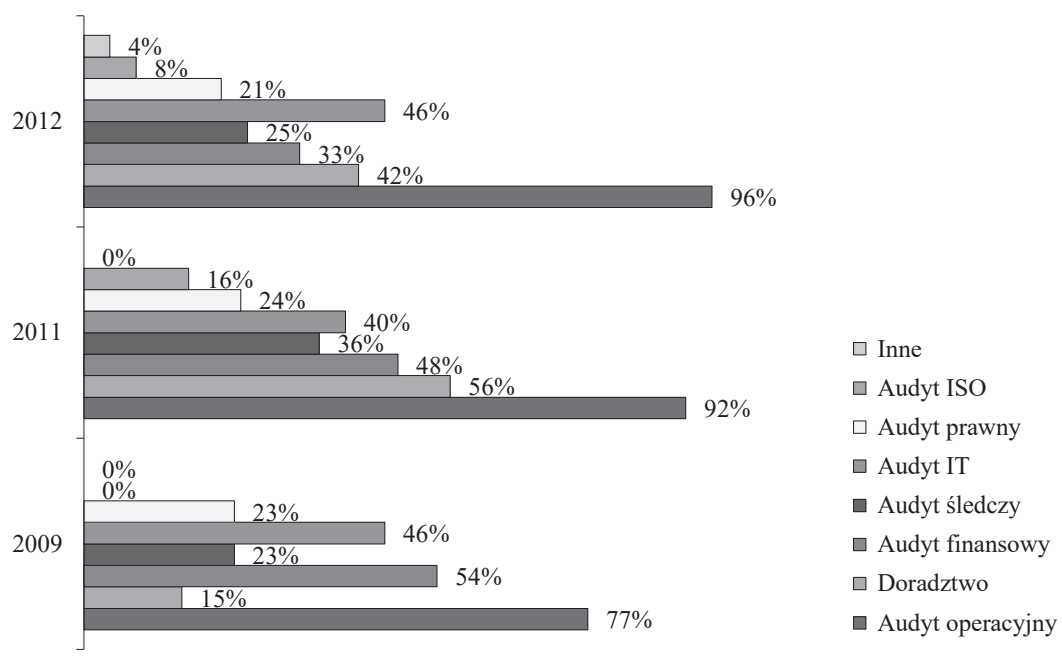

Rysunek 5. Zadania zrealizowane w ostatnim roku obrotowym

Źródło: Audyt wewnętrzny... (2013), s. 9.

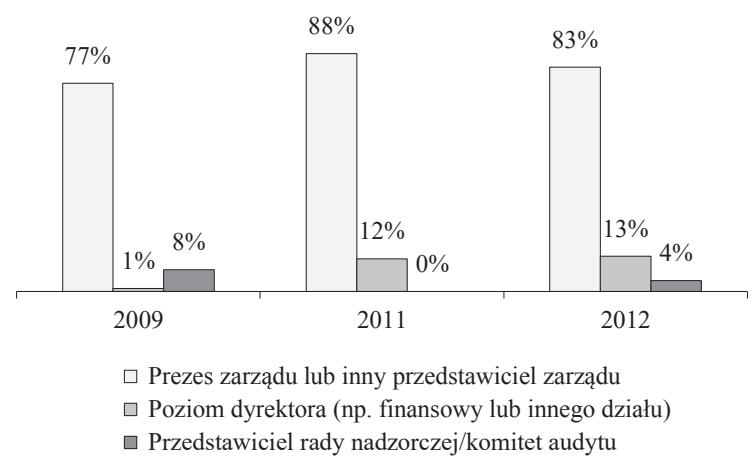

Rysunek 6. Podległość formalna audytu wewnętrznego

Źródło: Audyt wewnętrzny... (2013), s. 12.

Najpopularniejszą metodą dokonywania okresowej oceny korzyści funkcjonowania audytu wewnętrznego są statystyki rekomendacji zalecanych do wdrożenia (80\%). Sposób analizowania korzyści z funkcjonowania audytu wewnętrznego zaprezentowano na rysunku 7 . 


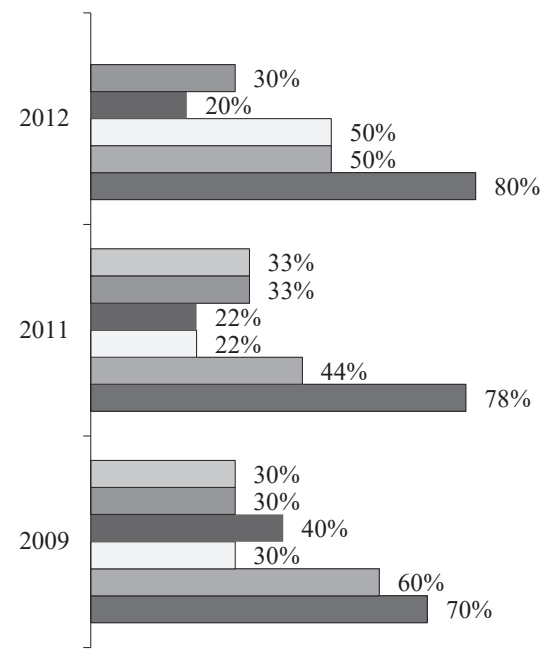
$\square$ Liczba zgłoszonych potrzeb na projekty zapewniające/doradcze ze strony kierownictwa spółki
$\square$ Ocena funkcjonowania audytu wewnetrzengo przez audytorów zewnętrznych
- Ocena korzyści finansowych z tytułu wdrożenia rekomendacji
$\square$ Ankiety/oceny ze strony audytowanego
$\square$ Liczba kluczowych obserwacji/rekomendacji z audytu
— Statystyka rekomendacji zalecanych/wdrożonych

Rysunek 7. Sposób analizowania korzyści z funkcjonowania audytu wewnętrznego Źródło: Audyt wewnętrzny... (2013), s. 17.

Niemal wszystkie ankietowane spółki przy planowaniu zadań audytowych bazują na ankiecie ryzyka, która uzupełniana jest przez wnioski z poprzednich audytów oraz wytyczne zarządu. Uzupełnieniem są wskazówki komitetu audytu i rady nadzorczej (rys. 8).

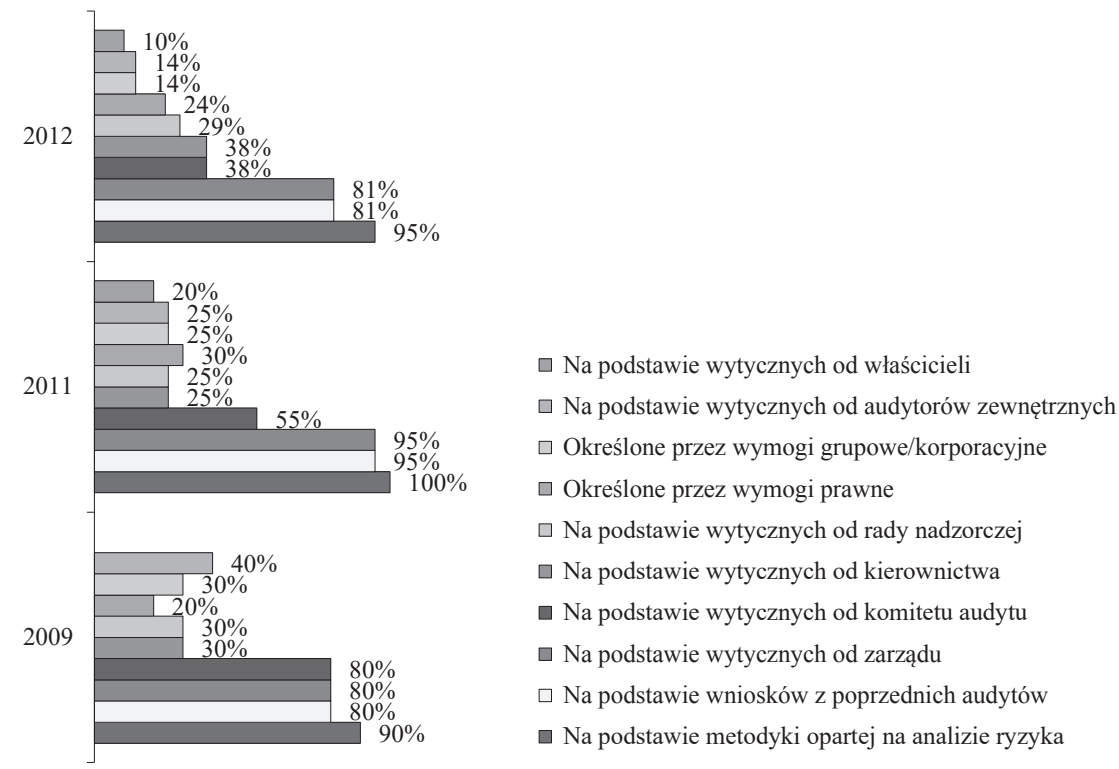

Rysunek 8. Podstawa definiowania zadań audytowych

Źródło: Audyt wewnętrzny... (2013), s. 19. 
Zmniejszenie udziału rady nadzorczej i komitetu audytu w definiowaniu zadań audytowych negatywnie wpływa na zakres planowanych zadań audytowych. Pozytywnie należy natomiast ocenić rosnący udział kierownictwa, co może sugerować, że audyt wewnętrzny jest akceptowany przez kierownictwo jako narzędzie doradcze, a nie kontroli.

\title{
Uwagi końcowe
}

W ankietach opracowanych przez instytucje audytorów wewnętrznych w Niemczech, Szwajcarii i Austrii oraz przez firmę audytową Grand Thornton w Polsce w latach 20092012 zapytano spółki o główne obszary zainteresowania i ranking czynności audytowych. $\mathrm{W}$ badaniach przeprowadzonych w krajach niemieckojęzycznych i w Polsce stwierdzono pojawienie się doradztwa w strategicznych decyzjach oraz wsparcie kierownictwa przez projekty zapewniające (doradcze).

\section{Literatura}

Alkafaji, Y., Hussain, S., Khallaf, A., Meldalawieh, M.A. (2010). Characteristics of an Internal Audit Activity. Report I, Institute of Internal Auditors, Altamonte Springs, FL.

Allegrini, M., D’Onza, G., Melville, R., Sarens, G., Selim, G.M. (2011). What's Next for Internal Auditing? Report IV, Institute of Internal Auditors, Altamonte Springs, FL.

Audyt wewnętrzny w polskich spótkach. Wyniki badania - edycja 2013, Grant Thornton.

Burnaby, P.A., Hass, S. (2009). A Summary of the Global Common Body of Knowledge 2006 (CBook). Study in Internal Aauditing, Managerial Auditing Journal, 24 (9).

Eulerich, M. (2014). Aktuelle Ziele und Zukunftsperspektiven der Interne Revision. Zeitschrift für Interne Revision, 5 .

Winiarska, K. (2017). Audyt wewnętrzny. Teoria i zastosowanie. Warszawa: Difin.

\section{ADVISORY FUNCTION ON THE BACKGROUND OF CURRENT AND PROSPECTIVE OBJECTIVES OF THE INTERNAL AUDIT}

\begin{abstract}
Purpose - The purpose of this article is to evaluate the performance of the advisory function in internal audit tasks.

Design/methodology/approach - Used survey institutes of internal audit and the audit firm.

Findings - According to the audit work conducted in the audit tasks, the respondents indicate advisory activities for the management of the units.

Originality/value - Thanks to foreign publications, information on the ranking of audit activities was obtained. Foreign auditors use contacts within internal audit institutes and benefit from greater financial capacity in surveys.
\end{abstract}

Keywords: internal audit, internal audit functions, internal audit advisory

\section{Cytowanie}

Winiarska, K. (2017). Funkcja doradcza na tle aktualnych i perspektywicznych celów audytu wewnętrznego. $F i$ nanse, Rynki Finansowe, Ubezpieczenia, 3 (87/1), s. 55-64. DOI: 10.18276/frfu.2017.87/1-05. 